\title{
The Change Dynamic of the Political Economy After the Global Crisis: The New State Capitalism
}

Gülenay BAŞ-DINAR (https://orcid.org/0000-0002-9532-4360), Department of Economics, Bolu Abant Izzet Baysal University, Turkey; e-mail: gulenaybasdinar@gmail.com

Serap DURUSOY (https://orcid.org/0000-0003-3430-2675), Department of Economics, Bolu Abant Izzet Baysal University, Turkey; e-mail: durusoy_s@ibu.edu.tr

\section{Küresel Kriz Sonrası Ekonomi Politiğin Değişim Dinamiği: Yeni Devlet Kapitalizmi}

\begin{abstract}
The current discussions on state capitalism are focused on whether post-crisis state capitalism practices can be a solution for the capitalism crisis. However, considering the change the concept of state capitalism has been through in time, it is important to study its relationship with the policies that emerged after the global crisis and led to new phase called "the new state capitalism". Within this framework, the object of this study is to review post-global crisis state intervention practices by taking into consideration the change state capitalism went through history and to analyse how these practices impact global capitalism. To this end, this study is divided into two sections: The first section will look at state capitalism from a historical perspective and tackle its differences from today's state capitalism practices. The second section will tackle the new state capitalism practices and their possible outcomes.

Keywords : Globalization, State Capitalism, Political Economy.

JEL Classification Codes: $\quad$ B14, B17, F62, N00.

\section{$\ddot{\mathbf{O} z}$}

Devlet kapitalizmi ile ilgili bugünkü tartışmalar temelde kriz sonrası devlet kapitalizmi uygulamalarının kapitalizmin krizine çözüm olup olamayacağı üzerine odaklanmıştır. Ancak, günümüzde devlet kapitalizmi kavramının zaman içerisinde geçirdiği değişim göz önüne alındığında küresel kriz sonrasında ortaya çıkan ve "yeni devlet kapitalizmi" olarak adlandırılan politikalarla ilişkisinin irdelenmesi önemli hale gelmiştir. Bu çerçevede bu makalenin amacı tarihsel süreç içerisinde devlet kapitalizminin geçirdiği dönüşüm göz önünde bulundurularak küresel kriz sonrası devlet müdahalesi uygulamalarını ele almak ve bu uygulamaların küresel kapitalizmi nasıl etkilediğini incelemektir. $\mathrm{Bu}$ amaç doğrultusunda çalışma iki bölümden oluşmaktadır. Çalışmanın birinci bölümünde tarihsel perspektiften devlet kapitalizmi incelenecek ve günümüzdeki yeni devlet kapitalizmi uygulamalarından ayrılan yönleri ele alınacaktır. İkinci bölümde ise, yeni devlet kapitalizmi uygulamaları ve olası sonuçları irdelenecektir.
\end{abstract}

Anahtar Sözcükler $\quad$ : Küreselleşme, Devlet Kapitalizmi, Politik İktisat. 
Baş-Dinar, G. \& S. Durusoy (2020), “The Change Dynamic of the Political Economy After the Global Crisis: The New State Capitalism”, Sosyoekonomi, Vol. 28(46), 407-424.

\section{Introduction}

The state has been an important actor in social and economic life throughout the history. The instruments and fields of state intervention have changed considerably in time in conjunction with social perception and political institutions. The state has been intervening in the economy starting from the end of the nineteenth century. These interventions have different characteristics both in technical (in terms of the use of political economy instruments) and in political (in terms of whose interest the state intervention serves for) terms. For this reason, while analysing the state's intervention in economic life, one must take into consideration the situation the world economy is in and the political conditions of the period (Szanyi, 2018: 140).

As a matter of fact, the change in economic and political conditions after the 2008 crisis intensified discussions about the way state intervenes in economic life. The fact that the number of state interventions in economy and companies owned or managed by state increased in developed and developing countries after the crisis brought the concept of state capitalism back to the forefront. However, even though practices of state capitalism guide international relations in economic and political terms, there is no consensus with regard to the definition of this concept.

Within this scope, it is important to eliminate the ambiguity regarding the concept of state capitalism to be able to understand the current functioning of global capitalism. The reason is that current discussions on state capitalism are focused on whether post-crisis state capitalism practices can be a solution for the capitalism crisis. However, taking into account the change the concept of state capitalism has been through in time, it is important to study its relationship with the policies that emerged after the global crisis and called "the new state capitalism". Within this framework, the object of this study is to review post-global crisis state intervention practices by taking into consideration the change state capitalism went through history and to analyse how these practices impact global capitalism. To this end, this study is divided into three sections: The first section will look at state capitalism from a historical perspective and tackle its differences from today's state capitalism practices. The second section will tackle the new state capitalism practices and their possible outcomes.

\section{State Capitalism Throughout History}

The concept of state capitalism has been used to describe interventions made by states in economic life since the end of the nineteenth century. State capitalism is sometimes used to describe state interventions in a capitalist economy and sometimes economic policies of the Soviet Union. In this sense, the concept is widely used both by Marxists leftists and liberal economists. In addition, the concept of state capitalism has assumed different definitions in different times. This led to an ideological differentiation in the meaning attributed to this concept.

The increasing state interventions in the economies of many countries after the crisis attracted more interest in state capitalism. However, in order to understand the types of 
intervention that steer the global economy today, we need to eliminate the ambiguity with regard to the meaning of state capitalism. Within this context, looking at the origins of the concept and seeing that economic politics that are defined as state capitalism refer to different situations through history make it more difficult to define state capitalism.

The focal point of conceptual discussions on state capitalism is the relation between state ownership and functioning of capitalist interventions. In this relation, the state sometimes has a certain degree of ownership over means of production, and sometimes it has great control over the activities of private economic actors. The first one of these situations refers to state capital while the latter refers to statism (Sperger, 2019: 102).

In a capitalist economic system, the government has always played an important role. In fact, Marx pointed out that the capitalist state underwent some serious roles to assure the accumulation of capital and to maintain its continuity. Although Marx had never ever provided a detailed and systematic state theory, in his work, he discussed the functions of capitalist states in detail (Miliband,1989: 8-9). In his work "The German Ideology", which he penned together with Engels, Marx analysed the relationship between the bourgeoisie and the state in detail. In this respect, Marx and Engels, highlighting that the bourgeoisie, as a social class, used the state to protect their own interest, emphasized that in societies where division of labour and the development of private property improves along with it, the hegemonic groups take the advantage of the state for their own benefit. Therefore, the state is defined as an organizational form that the bourgeoisie mandatorily accepts in return for the protection of their ownership and interest. According to Marx and Engels, there exists a conflict between an individual's own interest and that of the all members of the community in societies where division of labour and, along with it, the private ownership develops. This collective benefit that exists and manifests itself as the state does not actually reflect the interest of the society. The social class that obtains the financial power, in general, rules the state. The items defined as the collective benefits generally reflect the interests of the hegemonic group. Thus, the reality of the state develops into a fallacy through the common values, blood, language, division of labour etc. that exists in every community. According to Marx and Engels, all the battles- the battle among democracy, aristocracy and monarchy, the battles they fight for their right to vote are nothing but fallacious forms of the real battle that various social classes have been fighting take on. Any social class that desires its hegemony over the others, even if the ruling of this class would mean the disappearance of the whole existing societal style and even the sovereignty itself, has to present its own benefits as the interest of the whole (Marx \& Engels, 1992: 52-7).

As presented by Marx and Engels, in the capitalist system, the state represents the interests of the capitalist class. In other words, the state plays a vital role in the sustainability of the capital in such a way that it benefits the hegemonic class, the bourgeoisie. As a part of its this function in the system that governments actively resort to interventions when the flow of capital is interrupted. It has been observed that while these interventions are generally classified as the policy of the state control, sometimes, they are also referred as the state capitalism. Thus, in the course of the history, the state capitalism and the state control have been used interchangeably. For this reason, it is not possible to come up with a general 
definition of the concept the state capitalism. By dating back, the origin of this concept, the periods it is used and the types of economic structures it is used for and their correlation with the new economic policies described as the new state capitalism can be represented.

Tracing back, it is safe to say that this concept dates back to the end of the nineteenth century. Within this framework, in his paper where he studies the evolution of state capitalism, Sperger (2019) mentions five types of practices that referred to state capitalism through history. The first one is early Marxist views on state capitalism during the Second International, the second one is the Soviet Union's state capitalism against Europe's war experience and fascism during the first half of the 20th century, the third one is the state monopoly capitalism theories emerged in the West Block after the Second World War, the fourth one is the state capitalism practices emerged in the third world countries as a development strategy during the 1970 s and 80 s and the fifth one is the new state capitalism emerged after the 2008 crisis.

In his analysis, Sperger (2019) emphasizes that state capitalism practices have differentiated and within this framework, the meaning of state capitalism also transformed. Various ideological and political meanings were attributed to state capitalism. For this reason, it is not possible to talk about a single comprehensive definition of state capitalism (Sperger, 2019: 111).

The oldest known use of state capitalism dates back to the end of the $19^{\text {th }}$ century, to the Second International period. The concept of state capitalism became popular due to an increase of capitalist state concessions and during discussions on the shift towards capitalism. Within this framework, the concept of state capitalism was first used by Wilhelm Liebneckht in 1896, during the fourth Second International congress held in London to object to the claims that German Socialists were supporting state socialism. In this context, underlining that no one fought state socialism more than German Socialists, Liebneckht suggested that state socialism was state capitalism (Liebknecht, 1896). According to Liebneckht, true socialism can only be established by eliminating the capitalist state and the entire ruling bourgeoisie. For this reason, according to him, the concept of state socialism is an oxymoron and state capitalism in disguise (Sperger, 2019: 104).

The concept was also used in early Marxist discussions on the rise of monopolistic capitalism in European countries at the end of the $19^{\text {th }}$ century. According to Marx, capitalism's tendency to monopolize is an inevitable outcome of the process of capital accumulation. Competition among capitalists will force them to resort to technological development to improve labour productivity and seize more assets. Other competing capitalists will also follow the same path, and this will lead to a general rise in capital's organic composition and an increase in labour productivity, resulting in a decrease in profit rates. This process will cause powerless companies to either disappear from the market or be merged or acquired leading for the capital to accumulate in the hands of a lower and lower number of capitalists. For this reason, Marx considers capitalism's tendency to monopolize and centralize a logical outcome of accumulation. 
Similarly, in his study titled Socialism: Utopian and Scientific, Friedrich Engels highlighted that freedom of competition would morph into monopoly and the production in a capitalist society that is not based on any plan would start having to be done based on a plan just like in socialist societies. Within this framework, Engels also pointed out that the state, the legal representative of the capitalist society, would increasingly have to take control of production and the biggest change would take place in postal, telegram and railway services (Engels, 1970 (1880): 120-1).

Lenin stressed that monopolization did not eliminate competition and market decisiveness. The economic hegemony established by major international monopolies over the world market depends on the competition among these major monopolies. Within this framework and according to Lenin, such planning made in the level of companies in capitalism does not rule out market decisiveness. In capitalism, the state being a part of economic life like a major capitalist employer does not exclude individual private property, but rather strengthens it (Savran, 2011).

Aside from these Marxist views that emerged at the end of the $19^{\text {th }}$ century, the concept of state capitalism was used to describe the economic structure in Russia at the beginning of the $20^{\text {th }}$ century. Within this context, Lenin defined policies implemented during the NEP (New Economic Policy) period as state capitalism. This definition of Lenin describes a situation where workers' states allow individual private enterprise due to economic imperatives (Savran, 2011).

In addition, Binns (1990) claimed based on Marx's analysis on capitalism that the Soviet Union's economic structure could be described to be state capitalism rather than socialism. Within this framework, he suggested that post-1928 Russia was not in a better social order than the one in the West and that it was just as capitalist and imperialist like the one in the West. He pointed out that this was due to the fact that workers in the USSR had no control whatsoever over their own industrial branches or over state. In Russia, the state owns all means of production and workers are not the owners of the state as put forward by Marx. Therefore, Binns (1990) stresses the fact that means of production are owned by the state in Russia would not be sufficient enough to call Russia a socialist state and points out that even Western states show such non-capitalist features due to the rise of monopoly capitalism starting from the end of the 19th century. With the weakening of accumulation opportunities, state started intervening more and more. According to Binns (1990), one of the most prominent features of capitalism, which is that the general society is subject to accumulation, is present in Russia. In this period, the purpose of production in Russia is accumulation, not consumption like in capitalist nations. Within this framework, according to Binns, the process of accumulation for the sake of accumulation prevails in Russia back in the day just as in western capitalism.

Similarly, Cliff (2017) described Soviet Union's system as state capitalism. With this description, he referred to a regime where the state has a hold of means of production, the proletariat is deprived of all political and economic power, and the bureaucracy performs 
the duties and functions (taking away the surplus value from workers and increasing capital accumulation) of capitalism ${ }^{1}$ (Cliff, 2017).

On the other hand, Trotsky emphasized that by state capitalism, Marxists refer to the independent economic interventions of the state alone (Trotsky, 1979). Noting later that this concept assumed a wider scope of meaning and was wrongfully applied to all kinds of intervention introduced by the state in the economy, Trotsky pointed out the difference between "state capitalism" and "statism". The term "state capitalism" was often understood to mean state intervention and regulation during war times and especially during fascist economics experiments (Trotsky, 1998).

Starting from the rise of the international labour movement and socialism in the middle of the 19th century, it has been thought that state ownership is necessary for socialism in the face of capitalist private property. Within this context, what state ownership meant under capitalist conditions has been the focus of theoretical and political discussions among the working class, as well. That being said, there is no consensus about whether it is necessary to seize property of means of production to eliminate capitalist exploitation. As suggested by Savran (2011), in a situation where the political power is in the hands of the bourgeoisie and the entire social organism is subject to the logic and laws of capital accumulation (under capitalist conditions), state property cannot be anything more than a derivative of capitalist property. Even though the bourgeois state has to make concessions for the interests of the working class as a result of their struggle, it essentially meets the interests and needs of the capital. For this reason, enterprises operating under state ownership continue to be subject mainly to the logic of capitalism. Just like in private sector, employees in these enterprises also produce surplus value. Due to all of these, it would not be right to think of nationalization and expropriation to be socialism under the dominance of bourgeoisie and under capitalist conditions. In such cases, the state is the representative of the interests of the bourgeoisie as a class. In addition, just as under a private property regime, state property confronts nations with people. The capitalist society is divided among multiple states globally. Just like capital groups, these states are competing with one another in the global economy. State enterprises (Renault or Alcatel of France, SEES under the roof of IRI of Italy, and airline companies of European countries) are capitalist companies that compete for the sake of their national interests in global economy just like the monopolist private capital. Social character of modern producing powers manifests itself not only in a single country but worldwide (Savran, 2011).

1 However, this thesis by Cliff (2017) received significant criticism. The first criticism is that the concept of "state capitalism" can only mean something in a social order that includes capitalist private property along with state ownership over means of production. One cannot talk about capitalism when means of production are completely owned by the state. Therefore, it is suggested that the theory of state capitalism does not comply with the nature of bureaucratic regimes based on state ownership over means of production (Çağll, 2013). 
Baş-Dinar, G. \& S. Durusoy (2020), "The Change Dynamic of the Political Economy After the Global Crisis: The New State Capitalism", Sosyoekonomi, Vol. 28(46), 407-424.

Another period that was defined as state capitalism was post-Second World War. As previously mentioned, starting from the 1870s, the imperative tendency of capital to centralize and monopolize has manifested itself clearly as Marx pointed out in Das Kapital. Major cartels, corporations and trusts have started to take control of a huge chunk of the economy. This analysis, which was put forward by Marx after the World War Two, inspired state monopoly capitalism theories emerged in developed Western countries ${ }^{2}$.

The most important theory among these ones is of Baran and Sweezy. Baran and Sweezy (2007) highlighted that under monopoly capitalism conditions, the economic surplus tended to rise continuously, unlike Marx's "Tendency of the Rate of Profit to Fall" (Baran and Sweezy, 2007: 71-3). However, even though economic surplus continuously grows under monopoly capitalism conditions, the problem of the realization of surplus arises. Due to this problem, the economy tends to stagnate, and economies generally operate at idle capacity. For this reason, Baran and Sweezy underline that under monopoly capitalism conditions, a state has to heavily intervene in the economy to realize the ever-growing surplus. Within this context, it is of paramount importance to intensify advertising activities and increase public expenditure, especially military expenditure, to create new demands.

With the rise of monopoly capitalism, the state has extensively intervened in the economy. While market forces guided the economy during the period of competitive capitalism, where liberal policies were applied, the state assumed an important role in giving the capital accumulation the boost it needed by reducing profit rates and contracting production during the period of monopoly capitalism. Monopoly capitalism transformed into state monopoly capitalism through interventions like nationalization of basic industries, supporting some investments, controlling money and loan, creating a huge market for goods, engaging in $R \& D$ activities necessary for developing advanced technologies and regulating wages. This is considered to be the final stage of capitalism and the growing presence of the state in the economy is linked with the general crisis of capitalism (Jessop, 2002-2003).

Fourth phase of state capitalism emerged as a development strategy in third world countries in the aftermath of the oil crisis in 1973. Third world countries, which gained independence after the Second World War, were already aware of the fact that their political independence did not mean much without economic independence. For this reason, after gaining their political independence, the first goal of these countries was to develop. Having been colonies of developed countries for years, these countries were sceptical about the idea that they could achieve their economic development goals via a free market economy. On the other hand, the Soviet Union, which was a less developed country before the Bolshevik Revolution, becoming one of the most developed economies in the world in a very short time was a hope for these countries. However, not wanting to be a part of neither the Western

2 Chomsky (2009) has stated that the term state capitalism can be used to define the economic policies adopted during the period after the World War II as the government was the leading force for development and advancements (Chomsky, 2009). 
bloc nor the socialist bloc to be economically and politically independent, these countries relied heavily on state interventions to achieve their economic goals (Hunt, 2016: 667-8).

State involvement in economic problems continued heavily until 1970s in third world countries. However, state capitalism did not actually start taking shape in these countries until the oil crisis of 1973. Because in that period, an excessive increase in oil prices in developing countries, which were also oil-producers, and emerging market economies accelerated economic growth, resulting in a surplus of oil revenues in these countries. The fact that these countries, which had limited opportunities to make use of this foreign exchange reserve surplus within their countries, directed their reserve surplus to foreign investments, laid the foundation of the development of sovereign wealth funds, which is an instrument for new state capitalism (Yereli \& Yaman, 2017: 70).

\section{State Capitalism and Its Practices After the 2008 Crisis}

After the end of the Cold War, privatization and deregulation were advocated along with the Washington Consensus and interventionist state policies within the global economic framework received great criticism. IMF on the global economic platform. International financial institutions like the World Bank and the World Trade Organization imposing liberal policies in third world countries made it difficult for these countries to use state capitalism as a tool for development. Similarly, the decline of Marxism in the West and the loss of academic interest towards state monopoly capitalism theories made discussions on state capitalism in Western countries unpopular in 1990s and early 2000s. However, due to the global crisis at the end of 2000s, the striking difference of between growth performances of developed countries and developing countries that depend on heavy state intervention such as China and India revived the academic interest in state capitalism (Sperber, 2019: 109-10). While developed countries experienced major contraction in the aftermath of the crisis, developing countries like China, where the state played a crucial role in the economy, continued to grow.

The crisis in the US resulted in high rates of unemployment and serious contractions in the economies of countries that were considered to be the leaders of neo-liberal globalization, argued that free market economy would solve all financial problems and exaggerated the importance of the financial sector. Within this context, the fact that the financial sector, which is a very important pillar of capitalism, lies at the centre of this crisis raised the question of how global capitalism would survive (Ulagay, 2009: 24). Furthermore, the micro economic issues resulting from the economic crisis, as well as the global crisis itself, revealed that the American-style capitalism has also confronted some big scale issues and this made the discussions regarding the economic system an important issue (Stiglitz, 2012: 344-5). While it has been stated that the crisis was bought about by the dependency on neo-liberal policies and the market should be accused of that, discussions regarding the effects of state control on global economies to prevent loss of confidence in these policies and the burden that the state creates on the economy and its effects have been intensified (Piketty, 2014: 510). 
As it is known, Keynes pointed out a chronic problem of inefficient demand in developed capitalist economies and he suggested that the state should assume a regulatory role in the economy by offering proposals to increase consumption expenses and socialize investments (Keynes, 1973). With this proposal and the underlying model, developed capitalist countries experienced a period of relatively stable economic growth. However, Keynesian policies were blamed to be the culprit for the stagflation experienced in the early 1970s. During this period, theories such as the Monetarist School, Rational Expectations School and Supply Side Economics made it possible to defend neo-liberalism at a theoretical level. These theories that base the crisis on state intervention emphasized that free market economy should start to re-function. In 1990s, neo-liberalism and globalization became dominant strategies that drove global economy (Savran, 2013: 62-87).

After the global crisis in 2007, Keynesian policies made a comeback. At the core of these interventions lies the thought of alleviating the damage caused by the financial crisis on capitalists. However, state interventions in the post-2008 period were not only limited to monetary and fiscal policies. In some sectors state started to control the ownership of means of production. According to Wolff, this does not mean that capitalism eroded in developed capitalist countries. Wolff, who likened economic history to a pendulum swinging between "state capitalism" and "private capitalism", points out that there is no difference between means of production being in the hands of the state or private companies (Wolff, 2009).

Accordingly, shifting from one type of capitalism to another and policies implemented in every crisis make it difficult to define systems. As a matter of fact, the new state capitalism, which was used to define the growing new state capitalism to offer a solution to the post-crisis recession and improve the economic performances of countries, also includes these challenges. Because this new shape of state capitalism emerged differently in different capitalist society models (in developing and developed countries). Within this framework, Musacchio, Lazzarini and Aguilera (2015) point out that the new state capitalism is practiced differently. In some countries, the state has ownership of all enterprises and makes most of the investments while in other countries a small amount of investments is made by the state or some strategically important sectors are supported by it (Musacchio et al., 2015: 115). For that matter, the way state capitalism is practiced depends on the institutional and cultural structures and political conditions in a given country.

For example, state capitalism was used to define economic policy practices of developing countries such as Brazil, Saudi Arabia, Russia, India and Singapore after the crisis and within this framework, this concept mostly referred to excessive intervention of governmental powers in economic issues. However, the situation was different in these countries 20 years ago. After the dissolution of the Soviet Union, Russia shifted towards a Western-style economic model. With this new economic model, Russia started to adopt the economic values of the West and to improve its relations with its allies. Similarly, China introduced liberal market reforms. Emerging markets such as Brazil, India, Indonesia, South Africa and Turkey started to deregulate their economies and improve national private enterprise. Privatization started to gain popularity among Western European countries and international trade volumes increased. Globalization of consumer preferences, production 
Baş-Dinar, G. \& S. Durusoy (2020), “The Change Dynamic of the Political Economy After the Global Crisis: The New State Capitalism”, Sosyoekonomi, Vol. 28(46), 407-424.

chains, capital flows, foreign direct investments, technology and innovation further strengthened such trends. As mentioned before, a comeback was experienced from the free market economy after the crisis. The rise of state capitalism in these countries led to widespread inefficiencies and the inclusion of populist policies in economic decisionmaking processes. With the inclusion of political authorities in economic decision-making processes, a whole new set of winners and losers came about in global markets. During the Cold War, decisions taken by the administrators of Soviet and Chinese command economies had limited influence on Western markets. Today in developing countries, the state has started making economic decisions that would have a significant influence over global markets with regard to investments, property and market regulation (Bremmer, 2009: 40-3).

After the crisis, governments in developed countries initially considered the interventionist measures to be a temporary policy to get their economies back on track. However, these policies significantly damaged the free market doctrine, which was the theoretical basis of neo-liberal policies implemented starting from 1970s, over time. Even though neo-liberal policies are theoretically based on the free market doctrine, they involved considerable amount of state interventions starting from the moment they were introduced. A strong state was needed to introduce neo-liberal policies due to the dominance of market forces in response to reactions from the society and state unions in particular (Streeck, 2016: 95). Putting neo-liberal policies into practice was made possible through coups and constitutional amendments, especially in developing countries. For this reason, the goal of neo-liberal policies from the start was to turn the state's distribution relations in favor of capital. In this sense, it is safe to say that the base of state capitalism was ironically laid during the neo-liberal period.

Without a doubt, the capitalist state shaped itself once again after the crisis. Countries took measures to revive markets as economies signalled for recession. Some of these measures aimed at encouraging consumption through tax reductions and thus, reviving certain sectors. Aside from such measures, many banks and financial institutions were rescued by the state when faced with the risk of bankruptcy and, in a way, were nationalized. However, these policies required making compromises from budget and spending principles set out in the Washington Consensus (Kindleberger \& Aliber, 2013: 456). The rise of authoritarian capitalist countries during this period such as China and Russia were described in literature as a shift from the Washington Consensus to the Beijing Consensus. China's highly authoritarian economic development program was an attractive model not just for existing autocratic regimes in Asia but also for countries like Hungary and Turkey with growing authoritarian trends (Öniş, 2019: 203).

However, this economic model, which aims at stimulating the economy after overproduction cycles and bankruptcies and seems like it does not coincide with the capitalist process, does, in fact, not contradict with the logic of capitalism. Because state capitalism is an economic model that allows for the operation of the free market mechanism under the leadership and control of the state. So, one of the most important duties of a capitalist state is to secure capital accumulation processes. Therefore, as long as a state offers this assurance, it is of capitalist character (Saylan, 2016: 326). After the crisis, the state 
assumed a role in the economy by saving and securing capitalists that were on the brink of bankruptcy in some sectors.

As a matter of fact, the money spent for saving the financial system in the US, Britain and the Euro Zone alone reached 14 trillion US Dollars. In this case, it is not surprising that the state was considered to be the sole remedy to save capitalism from the crisis in a period where state interventions were criticized, and market virtues were praised. Because, in this case, state intervention was obligatory for the continuation of the system (Mason, 2016: 364). However, even though these interventions were introduced as a remedy to the crisis of capitalism, they had some adverse impacts on the global economy. First of all, these interventions pushed countries into a fiscal crisis and second of all, many countries adapted state capitalism to their own economic and political circumstances.

Although, in today's state capitalism, the intervention of the state in economy or the state acting as an entrepreneur differs depending on time and geography, in reality, its main aim is to create the required environment for the accumulation of capital and look out for its benefits in the short, medium, and long term. However, today, the state intervention has become a common and systematic approach rather than being a temporary one-off application. This state activism can also be interpreted as the rediscovery of the state's political supervision on economy (Clift, 2019: 216). In fact, Poulantzas also states that the reproduction of capitalism benefits the state itself (Prezeworski, 2014: 132-3). The process applied through this period can lead the government to use the markets to increase its economic power and political influence, and cause the political preferences the public interest to come to the forefront and the economic priorities to fall behind the political priorities (Scharpf, 2014: 437-44). Consequently, this new condition that can be defined as the politicization of the economy, has become a long-term strategy rather than a temporary precaution taken after the economic crisis ${ }^{3}$ (Atl1, 2015: 305).

However, it can be said that both the style and the intervention methods of the new state capitalism are structured differently (Stiglitz, 2012: 323). While the intervention types are limited to cash and credit arrangement, financial regulations, trade controls and labour market due to the traditional functions of the capitalist state, these interventions in the new state capitalism (<https://www.economist.com/leaders/2012/01/21/the-rise-of-statecapitalism >) that provides greater power to the politicians include keeping public enterprises from public auditing, nationalization of the key sectors and creating new sources for loan. These interventions diversify depending on the composition of the hegemonic class, the existing structures and the institutions in the government, scale of the rights and liberty, the

3 Piketty asserts that the easiest way to evaluate the change that the role of the state underwent in the economic life and communal living is the taxation, measure the weight of any other responsibilities in overall domestic income, intervene by passing regulations and to produce and provide capital (Piketty, 2014: 511-3). 
course of class conflicts and the shift in the balance of the political powers (Jessop, 2013: 434-5).

According to Bremmer, the new state capitalism implements these interventions through four instruments. These are sovereign wealth funds, national oil companies, stateowned enterprises and supporting national private equity champions.

As it is known, the monetary policy was the first policy introduced to achieve economic balance after the crisis. As a matter of fact, after the housing market bubble burst in 2007, the Obama administration introduced state funds into the market in order to compensate for the banks' mortgage losses. Through this policy, financial assets lost by the banking sector due to mortgages were purchased through state resources (Ürünlü, 2014).

After 2005, the year until which global capital flows were controlled by Western countries, due to the rise of sovereign wealth funds, the dominance of Western countries over global capital flows started to get weaker. During the oil crisis, US and European financial markets mostly invested in fixed-yield instruments while in new state capitalism, investments are also made in other instruments besides state funds and fixed-yield instruments. In addition, control and management of funds are not left to developed countries. In other words, Western financial institutions were gone from managing the fund to broking. Within this context, in state capitalism, emerging economies started to gain importance compared to the liberal capitalism period. Summers considered these funds, which reshaped the global financial system and shook the logic of capitalism to its core, as an irony of the global financial system (Summers, 2007).

Decisions to invest in these funds were heavily influenced by political situations and political authorities started to make use of funds to get political and financial gain. This is why the IMF demands utmost transparency and consistency for these funds. Today, policymakers in China, India and Russia are at the heart of the global financial system. The administrators of treasury and finance injecting liquidity into the economy to save private banks and companies caused a significant shift at the core of the global financial power. As a matter of fact, New York was considered to be the financial capital of the world until recently, but it became the financial capital of the US due to state interventions (Bremmer, 2009: 45-6).

Another instrument for widespread implementation of the new state capitalism is the expropriation of key sectors. Energy is the sector where this instrument is the most popular. With energy becoming increasingly important for the economy and rising energy prices, governments in developing countries made major investments in national energy companies. This way, governments of these countries were able to take control of almost all of the natural and most valuable resources of their countries. Previously, global energy markets were dominated by seven companies, which were called "the seven sisters", namely Standard Oil of New Jersey, Royal Dutch Shell, Anglo-Persian Oil Company, Standard Oil of New York, Standard Oil of California and Gulf Oil and Texaco. Today, however, governments own the world's largest oil companies and have control over three fourths of 
global energy reserves. The world's largest oil companies are the ones that are owned and operated by governments such as the Saudi Aramco of Saudi Arabia, the National Iranian Oil Company of Iran, Petroles de Venezuela of Venezuela, Gazprom and Rosneft of Russia, National Petroleum Company of China, Petronas of Malaysia and Petrobras of Brazil. Stateowned companies have control over $75 \%$ of the global oil reserves and global oil production. Some governments extended state ownership over energy resources by defining them strategic assets. Within this context, most governments have control over this sector to process energy resources much more and to better fund them than their competitors (Bremmer, 2008: 56-7).

Even though state-owned enterprises are most popular in the energy sector, there are some other examples in strategic fields such as petro-chemistry, mining, iron and steel production, port administration and shipping, arms manufacturing, automotive and telecommunications. By extending the scope state property in such strategic fields, governments seek to improve power in global markets and deepen their political positions (Bremmer, 2010: 166-70). State-owned companies such as Endiama EP (diamond) of Angola, Azer Energy (power generation) of Azerbaijan, and Kazatomprom (Uranium) of Kazakhstan have become the world's biggest actors in their fields (Bremmer, 2009: 42-3).

These state-controlled companies also play an active role in capital markets. The share values of these state-owned companies in capital markets are very high. This share is $80 \%$ in China, 62\% in Russia and 38\% in Brazil. We can see the power of state-owned companies in developed countries, as well. In France, $85 \%$ of the energy company EDF is controlled by the state while $50 \%$ of Japanese Tobacco and $32 \%$ of Deutsche Telekom are controlled by the state (Yüzak, 2012). 13 oil companies, which have control over threequarters of the global oil reserves, are partnered or supported by various countries. Russia's natural gas monopoly Gazprom, China's China Mobile with 600 million users, the mostprofitable petro-chemical company Saudi Basic Industries Corporation, the world's thirdlargest bank Russian Sberbank, Emirates Airlines and the world's third-largest port authority Dubai Ports are state-owned companies. In addition, the fact that companies are spread over a wide area and are international is another distinctive feature of today's state capitalism.

Another means used to implement the new state capitalism are policies encouraging leader companies that are privately-owned and called "national champions". In some developing countries, large companies operating in strategically important areas are strongly supported by the government through loans, contracts and a number of means. These companies that are called "national champions" are subject to private ownership while receiving intense support from the government to compete with foreign commercial competitors. Thanks to this governmental support, these companies play a dominant role in the national economy and in export markets. It is known that such companies, also known as "national champions" in developing countries, generally have close ties to the government. For example, "national champions" in Russia are controlled by a group of oligarchs who have strong personal ties with Kremlin. The way these companies are financed is of vital importance. If governments try to finance these "national champions" by printing money, this would lead to inflation. State wealth funds play an important role in financing 
these companies as covering the expenses from the state budget may lead to budget deficit. On the other hand, these funds serve as depository for foreign currency earned from the export of goods produced. Sovereign wealth funds are beyond bank accounts and are stateowned investment funds mixed with instruments such as government bonds, real assets, precious metals, etc. (IMF, 2008). Like all other investment funds, sovereign wealth funds aim to maximize returns. For state capitalists, these returns are as political as they are economic (Bremmer, 2009). Sovereign wealth funds of China, Saudi Arabia, Abu Dhabi and Kuwait have shares in the world's largest banks. Globally, sovereign wealth funds have control over an asset of 4.8 trillion US Dollars. The largest share, which corresponds to 1.5 trillion US Dollars, in this is controlled by China (Yüzak, 2012).

With the rise of new state capitalism, state also introduced fiscal interventions after the crisis and had direct control over redistribution and prices through taxation. This change in economic, social and political spheres along with the shift from the classical state approach to the interventionist one, also had an impact on taxation (Hirsch, 2011). Today, aside from its conventional financial function, non-financial functions of taxation have begun to gain importance. Taxes were used more intensively to direct economic and social policy aside from their financial function due to new functions assumed by the state in financial and social fields. Intervening into economy through taxes has not taken place only by means of tax increases or reductions but also by means of exempting some sectors from $\operatorname{tax}$ (Ay, 2008: 100).

As it is clear, despite the global crisis of capitalism, the state has a major role in ensuring the continuity of capitalism. Interventions introduced by the state to reproduce capitalism also discipline labour within its borders. This situation has led to a more oppressive environment where individual freedom is increasingly limited (Savran, 2013: 152-7). Stagnation of economy due to the crisis has aggravated working and living conditions for workers. The main issue to focus on are the consequences of government policies that encourage saving rather than consumption like in China. While keeping consumption opportunities at a low level through state policies, the Chinese government has introduced a number of policies to increase savings. Even though the savings rate was $45 \%$ of the GNP in 2018 as a result of these policies, income generated by the Chinese in return for their savings was very limited. The state achieved this by keeping the currency value below its market value. This way, foreign investment is encouraged by having imported inputs get expensive and exported products cheap. On the other hand, with ceiling rates applied to savings in banks, interest rates were kept low and cost of people's savings was artificially reduced below market value. Through these policies, savings of laborers were systematically fed into state enterprises as cheap source of finance. Using the savings of workers as cheap source, the state's act to sustain the cheap source of financial investment by leading people to savings and limiting consumption opportunities led to the impoverishment of labour, thus insufficient demand, resulting in stagnation of the economy. In addition, increasing poverty resulted in resistance by societies (Saylan, 2016: 357; Savran, 2013: 157-8). 
In this context, it is safe to say that state capitalism poses important risks for the functioning of global markets. First of all, commercial decisions are often made by political bureaucrats with little experience in effectively managing commercial transactions. This causes state-owned enterprises or national champions to experience issues such as bureaucracy, waste, and political nepotism. A close interaction between political and economic processes makes markets less competitive and therefore less efficient. Secondly, these enterprises pose a growing threat to their competitors in private sector because they are able to enjoy competitive advantages offered by strong political figures and state support. For example, in China, national oil companies have more cash than their private sector competitors due to state funds. Such practices disrupt the performance of energy markets by increasing the costs for anyone paying for oil and gas. This also results in multinational energy companies to be deprived of additional income they require for expensive long-term projects and prevents them from being involved in expensive long-term projects such as marine research. Thirdly, motivation behind an investment decision is of political nature rather than financial. This prevents markets to run efficiently due to politics and, with it, high-level of corruption being involved in production (Bremmer, 2008: 57-8).

Popularization of new state capitalism leads to bureaucratic waste, inefficiency and corruption to increase. These problems are more common in authoritarian states. These issues are especially more common in countries where political authorities have the freedom to take commercial decisions without the presence of free press or politically independent regulatory authorities and lawmakers (Bremmer, 2009).

In capitalism, as it exists today, the state has gained an increasing power that can merge the national capital with global markets, compete with global markets and create opportunities for new profitable investments. In theory, even during the neoliberal era when the whole purpose was to establish a market hegemony in every field, the state provided the appropriate conditions for primitive investment by changing the division of the shares to favour the capital and privatizing certain public funding. Thus, privatization that played a great role in putting neoliberalism into practice became one of the fundamental tools of the government in releasing the assets the state owned or the assets belonging to the community property. In this framework, new profitable areas were created and the issue of overaccumulation that burdens the accumulation period was, at least temporarily, tackled (Harvey, 2008: 131). This has assigned the state the role of an active provider of the accumulation process. The inadequacy of capital accumulation in developing countries led to a more radical state intervention in economic life. Therefore, Harvey describes neoliberalism as a political project that provides required conditions for capital accumulation (Harvey, 2015: 27). Like Harvey, Polanyi also emphasizes that markets are not self-creations as the theory suggests but are created by a government that imposes a common market organization on the community either deliberately or by force (Polanyi, 2008: 333). Neoliberal policies create an unlimited market freedom for financially robust companies by abolishing the regulatory precautions, to a considerable extent, in every sector from airline companies to tele-communication, and finance. With the abolishment of these regulations, the markets presented as the only means of competition of the neoliberal ideology and improving innovation became a tool to consolidate the monopoly power (Harvey, 2015: 34). 
Baş-Dinar, G. \& S. Durusoy (2020), “The Change Dynamic of the Political Economy After the Global Crisis: The New State Capitalism”, Sosyoekonomi, Vol. 28(46), 407-424.

\section{Conclusion}

Today, even though practices of state capitalism guide international relations in economic and political terms, there is no consensus with regard to how to define the concept. The fact that economic politics that are defined as state capitalism refer to different situations through history make it more difficult to define state capitalism. For that matter, in order to understand the current functioning of global capitalism, the ambiguity with regard to the meaning of state capitalism must be eliminated and the transformation of state capitalism through history must be taken into account. Because state capitalism practices have experienced significant changes at different times in different countries. Post-2008 new state capitalism practices are very much different than state capitalism practices of the past.

In literature, the concept of new state capitalism is mostly discussed through instruments such as sovereign wealth funds, national oil companies, state-owned enterprises and national champions. However, new state capitalism includes more interventions then these ones. During this period, state intervened radically to support the capital's interests and regulate distribution relations. On one hand, the government regulates the division of affairs favouring the capital by controlling the cash and the credits, financial regulations and oppressing the labour based on the traditional function of the government after the crisis, on the other hand, it plays an active role by giving power to the politicians via keeping public enterprises from public auditing, nationalization of the key sectors and creating new sources for loan, and by supporting public enterprise in global markets or certain sectors. Today, competition in global markets manifests itself not only economically but also politically. With the rise of new state capitalism, competition has transformed into a political character. Since competition no longer takes place between companies but between states, it would be safe to say that new state capitalism is a strategy to maintain transnational capitalism. However, this distinctive feature of today's state capitalism has adverse impacts on the functioning of global capitalism. Practices that have a political agenda and control the market and welfare through state-dominated companies and institutions aim at sustaining the capitalist system while weakening the foundation on which global capitalism is built.

In January 2012 issue, the Economist covered the possible consequences of state capitalism practices. Within this framework, it was underlined that direct or implicit support offered to public-owned companies by states might lead to an unlevel playing field for competition and financial corruption. Due to these drawbacks, it is safe to say that new state capitalism practices, which were considered a solution for the crisis after the crisis, are far from offering a permanent solution for the crisis of capitalism. Because it is highly likely that the expected success of the new state capitalism also brings about a failure created by state capitalism itself.

\section{References}

Atlı, A. (2015), "Değişen Çin ve Dünya Düzenindeki Rolü”, in: F. Şenses \& Z. Öniş \& C. Bakır (eds.), Küresel Kriz ve Yeni Ekonomik Düzen, İstanbul: İletişim Yayınları, 285-310.

Ay, H. (2008), Vergi Politikaları ve Baskı Grupları, Ankara: Maliye ve Hukuk Yayınları. 
Binns, P. (1990), Rusya 'da Devlet Kapitalizmi, (Çev. A. Saffet \& T. Kaya), İstanbul: Sosyal İşçi Yayınları.

Bremmer, I. (2008), “The Return of State Capitalism”, Global Politics and Strategy, 50(3), 55-64.

Bremmer, I. (2009), “State Capitalism Comes of Age: The End of the Free Market?", Foreign Affairs, 88(3), 40-55.

Bremmer, I. (2010), The End of The Free Market, USA: Portfolio.

Chomsky, N. (2009), "Chomsky: Understanding the Crisis-Markets, the State and Hypocrisy", Sameer Dossani, February 10, Foreign Policy in Focus,

<https://web.archive.org/web/20090902080737/http://www.fpif.org/fpiftxt/5860>, 10.07.2020.

Cliff, T. (2017), Rusya'da Devlet Kapitalizmi, (Çev. R. Margulies \& T. Kaya), İstanbul: Z Yayınları.

Clift, B. (2019), Karşılaştırmalı Siyasal Ekonomi, Devletler Piyasalar ve Küresel Ekonomi, İstanbul:

Koç üniversitesi Yayınları.

Çağl1, E. (2013), “Devlet Kapitalizmi” Teorisinin Eleştirisi, <https://www.cangungen.com/2013/12/23>, 22.12.2019.

Economist (2012), "State Capitalism”, Special Report, 21-27, January, <https://www.economist.com/leaders/2012/01/21/the-rise-of-state-capitalism>, 29.12.2019.

Engels, F. [1970 (1880)], Socialism: Utopian and Scientific, <https://www.marxists.org/archive/marx/works/download/Engels_Socialism_Utopian_an d_Scientific.pdf>, 01.12.2019.

Harvey, D. (2008), Yeni Emperyalizm, (Çev. H. Güldü), İstanbul: Everest Yayınları.

Harvey, D. (2015), Neoliberalizmin Kısa Tarihi, (Çev. A. Onacak), İstanbul: Sel Yayıncılık.

Hirsch, J. (2011), Materyalist Devlet Teorisi, (Çev. L. Bakıç), İstanbul: Yeni Alan Yayıncılık.

Hunt, E.K. (2016), Ikktisadi Düşünce Tarihi, (Çev. V.U. Aslan), Ankara: Phoenix Yayınları.

IMF (2008), Sovereign Wealth Funds, A Work of IMF, February 29,

<https://www.imf.org/en/Publications/Policy-Papers/Issues/2016/12/31/Sovereign-

Wealth-Funds-A-Work-Agenda-PP4234>, 24.12.2019.

Jessop, B. (2002-2003), "Yakın Dönemde Kapitalist Devlet Teorileri”, in: (Çev. Ö. Yakupoğlu), Teori ve Politika, 28-29, <https://www.teorivepolitika.net/index.php/okunabiliryazilar/item/336-yakin-donemde-kapitalist-devlet-teorileri>, 22.12.2019.

Jessop, B. (2013), Devlet Teorisi: Kapitalist Devleti Yerine Oturtmak, Ankara: Epos Yayınları.

Keynes, J.M. (1973), The General Theory of Employment Interest and Money, İngiltere: Macmillan.

Kindleberger, C.P. \& R.Z. Aliber (2013), Finansal Krizler Tarihi, (Çev. Ü. Şensoy), İstanbul: Türkiye iş Bankası Kültür Yayınları.

Liebknecht, W. (1896), Our Recent Congress, <https://www.marxists.org/archive/liebknechtw/1896/08/our-congress.html>, 23.12.2019.

Marx, K. \& F. Engels (1992), Alman İdeolojisi, (Çev. S. Belli), Ankara: Sol Yayıncılık.

Mason, P. (2016), Kapitalizm Sonrası Geleceğimiz İçin Bir Kılavuz, İstanbul: Yordam Kitap.

Miliband, R. (1989), Kapitalist Devlet, (Çev. O. Akınhay), İstanbul: Belge Yayınları.

Musaacchio, A. \& S.G. Lazzarini \& R.V. Aguilera (2015), "New Varieties of State Capitalism:

Stratejik and Governance Implications", The Academy of Management Perspectives, 29(1), 115-131. 
Öniş, Z. (2019), "Turkey under the challenge of state capitalism: the political economy of the late AKP Era", Southeast European and Black Sea Studies, 19(2), 201-225.

Piketty, T. (2014), Yirmi Birinci Yüzyılda Kapital, (Çev. H. Koçak), İstanbul: Türkiye İş Bankası Kültür Yayınları.

Polanyi, K. (2008), Büyük Dönüşüm, (Çev. A. Buğra), İstanbul: İletişim Yayınları.

Prezeworski, A. (2014), Kapitalizmde Devlet ve Ekonomi, (Çev. E. Kırmızıaltın \& A. Özinak), Ankara: Heretik Yayınları.

Savran, S. (2011), "Devlet Mülkiyeti: Toplumsal Mülkiyete Giden Yol: 'Yeni Bir Kamusal Alan' Tarifinin İmkansızlığı”, PGBSosyalizm, 19, <https://pgbsosyalizm.org/?p=71>, 15.12.2019.

Savran, S. (2013), Üçüncü Büyük Depresyon, İstanbul: Yordam Kitap.

Saylan, G. (2016), Değişim Küreselleşme ve Devletin Yeni İşlevi, Ankara: İmge Kitabevi.

Scharph, F. (2014), "Küreselleşme ve Kapitalist Demokrasilerin Ekonomi Politiği”, in: D. Held \& A. McGrew (eds.), Küresel Dönüşümler: Büyük Küreselleşme Tartışması, (Çev. E. Akçakoca), Ankara: Phoenix Yayınları.

Sperger, N. (2019), “The Many Lives of State Capitalism: From Classical Marxism to Free-Market Advocacy", History at the Human Sciences, 32(3), 100-124.

Stiglitz, J.E. (2012), Serbest Düşüş, (Çev. B. Özgün), İstanbul: Gündoğan Yayınları.

Streeck, W. (2016), Satın Alınan Zaman Demokratik Kapitalizmin Gecikmiş Krizi, (Çev. K. Kabaday1), 92, İstanbul: Koç Üniversitesi Yayınları.

Summers, L. (2007), "Funds that Shakes Capitalist Logic", Financial Times, 29.07.2007, <http://www.ft.com>, 29.12.2019.

Sweezy, P. \& P. Baran (2007), Tekelci Sermaye, (Çev. G. Akalın), İstanbul: Kalkedon Yayınları.

Szanyi, M. (2018), Varieties of State Capitalism, Global Economic Observer, 6(2), 140-146.

Troçki, L. (1979), Sovyet Devletinin Sinıf Karakteri, (Çev. A. Erdem \& Z. Dağlar), İstanbul: Enternasyonal Yayınları.

Troçki, L. (1998), İhanete Ŭgrayan Devrim, (Çev. A. Ortaç), İstanbul: Yazın Yayıncılık.

Ulagay, O. (2009), Küresel Çöküs ve Kapitalizmin Geleceği, İstanbul: Özgür Yayınları.

Ürünlü, C. (2014), İktisat Tarihinde Kapitalizme Elveda Aşaması, <http://www.urunlu.com/117iktisat-tarihinde-kapitalizme-elveda-asamasi>, 29.12.2019.

Wolff, R. (2009), “Krizler, Kapitalizmin Bir Islah Olma Aracıdır”, Birgün Gazetesi, 11.03.2009.

Yereli, A.B. \& İ. Yaman (2017), “Ulusal Varlık Fonlarını Anlamak Firsat Mi Tehdit Mi?”, Sosyoekonomi, 25(34), 69-86.

Yüzak, Ö. (2012), "Yükselen Güç Devlet Kapitalizmi”, Cumhuriyet Gazetesi, 01.02.2012. 